\title{
MINDEORD
}

\section{ET PERSONLIGT MINDEORD OM NIELS FOCK}

Min fremragende gamle lærer fra Institut for Antropologi, docent (1967-97) Niels Fock, er død kort før nytår. Han var præcis fem dage ældre end min far, og der var i sandhedens tjeneste noget faderfigur over ham. Han nåede den flotte alder af 93. Fock var elev af Birket-Smith fra den tid, hvor undervisningen af den lille håndfuld etnografistuderende foregik som en begavet samtale omkring et bord på Etnografisk Samlings bibliotek på Nationalmuseet. Birket-Smith deltog i Femte Thule-ekspedition, og således var Fock min underviser i antropologi med håndspålæggelse fra Knud Rasmussen i blot tre led.

Første gang min årgang mødte ham, var, da han troppede op i auditoriet $\mathrm{i}$ Frederiksholms Kanal 4 iført vest og pibe. Han tog piben ud af munden og sagde langsomt og højt: „Jeg tilhører en generation af antropologer, som tog et helt kontinent“ - kunstpause - „Sydamerika!“ - kunstpause - „Højland. Lavland. Pampas“. Og så snadden ind igen. Så var han ligesom præsenteret.

Fock rejste som ung mand til waiwaiindianerne i Britisk Guyana, hvor han fik fantastiske data med hjem. Blandt andet har han skrevet om waiwaiernes såkaldte ceremonielle dialoger, hvor de sidder i hængekøjerne og forhandler politisk efter nogle fastlagte ritualer, hvor man time efter time skal kommentere på modpartens argumenter med et uendeligt $\mathrm{O}$ ho!, så det bliver en slags chant. Det er $\mathrm{i}$ virkeligheden en udtrætningsmanøvre, hvor eventuelle uenigheder afvejes mod mangel på fysisk komfort ved at fortsætte „debatten“. Ikke ulig Brexit op til jul. Fock havde også fantastiske genstande med hjem fra waiwai; genstande, som i dag mestendels ligger på magasinerne på Nationalmuseet. Han skrev sin doktordisputats om dette regnskovsfolk i 1963.

Siden søgte Fock op i Ecuadors højland. Andesindianernes udprægede sans for strukturel tænkning honorerede både Niels Focks ditto og den franske etnograf og teoretiker, Claude Lévi-Strauss, hvis vanskelige, men ekstremt intelligente og morsomme teorier og etnografier vi gennemtrawlede med Fock. Hans 
forelæsninger var fremragende; han talte i oneliners og skelede kun i ny og næ til det okkergule manuskript.

Det er en gave for livet at være blevet taget med ind i et læringsrum med så fagligt krævende diskussioner - og at være blevet taget alvorligt dér. Fock var en teoretisk elegantier med humor og god sans og observationsevne for ikkeeuropæiske menneskers partikulære særheder. Han var bestemt ikke til følelser og „synsninger“ - hvilket gav ham problemer i den munkemarxistiske periode, men så meget desto mere ville man vide, hvad han vidste. Han var også meget glad for sprog. Jeg husker, at han engang kritiserede en tanke, jeg havde, for at være „både forarmet og forbenet“. Det var hårdt sagt, men fuldstændig sandt, og fordi vi grinede højt af det herlige sprogbillede, har jeg jo aldrig glemt det: Tænk ikke forarmet eller forbenet! Han sagde også altid: Spørg ikke hvorfor, spørg hvordan. Kausalitetserklæringer forbandt han med ideologi og „,synsninger"; sammenhænge og mønstre - hommage à Lévi-Strauss - var derimod dét, det drejede sig om. Det glemmer jeg heller aldrig. Niels Fock stillede meget høje krav til sig selv, han var altid velforberedt til gavn for sine studerende, og han krævede noget af os. Hans store faglighed i kombination med hans neddæmpede, nærmest kølige ro og grundighed gjorde, at man virkelig ikke ville skuffe ham. Han var en såkaldt naturlig autoritet.

Jeg kan illustrere det med en episode, da jeg og to andre skrev fjerdesemesteropgave (det var før bachelor) om de fantastiske kunaindianere på San Blas-øerne i caribisk Panama. Vi var gået i tre forskellige retninger; jeg havde fortabt mig $\mathrm{i}$ vanvittigt sjove beretninger fra en britisk kaper i 1600-tallet, som jeg havde fundet på Det Kongelige Bibliotek. Denne kaper havde stjålet adskillige skibe fra deres ulykkelige kaptajner, blandt andet et dansk skib, som han tog alene, „fordi hun var så smuk“", men på et tidspunkt blev han sat i land af et crew, der var blevet trætte af ham. Det land var kunaernes land, og kaperen havde fantastiske beskrivelser af kuna med deres afskårne sorte pagehår, bemalede kroppe og guldsmykker; han boede hos dem $\mathrm{i}$ årevis og beskriver blandt andet deres kosmosopfattelse, som vi så kunne sammenligne med ditto i nutiden, mente jeg. En anden af os var i gang med at skrive om kunaindianernes såkaldte „mola“, som er rektangulære stofpaneler syet $\mathrm{i}$ hånden $\mathrm{i}$ en kompliceret applikationsteknik, hvor de gennem motiverne bearbejder moderniteten, der trænger sig ind på dem. Niels Fock havde naturligvis en sådan mola hængende på sit lille kontor under de skrå vægge øverst $\mathrm{i}$ Frederiksholms Kanal, som man kunne beundre gennem piberøg, når man modtog kort og koncis vejledning formuleret i oneliners. Den tredje af os skrev specifikt om kunas politiske ceremonier, som netop minder lidt om waiwais ved at være præget af rituelt gentagne call and response-former i en uendelighed. 
Vi havde med andre ord slået et kæmpe brød op til vores fjerdesemesteropgave, og vi ville så nødigt skuffe Niels Fock ved ikke at komme i land med den. Ikke at kunne komme i land skulle blive aktuelt også i mindre metaforisk forstand, da vi besluttede at tage $i$ et sommerhus for at få skrevet kapitlerne sammen til et hele. Som overspringshandling skulle vi dog først have os en rotur på Sejerøbugten, og vi satte prompte fra land i en ældre robåd. Da vi kom fri af Ordrup Næs, knækkede åregaflen pludselig af rælingen, samtidig med at vinden tog båden udad, udad, udad i afdrift og fralandsvind. Kun ved en komisk Anders And-agtig indsats bestående $\mathrm{i}$ at to af os roede som gale galajslaver, mens den tredje holdt åren fast på rælingen med hænderne, kom vi inden for Ordrup Næs igen, hvorved vi efter nogle timer kunne padle os $i$ land.

Det sigende ved episoden er, at det eneste aspekt ved at drive til havs, der bekymrede os overhovedet, var ikke angsten for at lide druknedøden i ung alder, men den ekstreme flovhed og skam, der ville overgå os, ved at vi måske ville blive fundet som afsjælede unge legemer i brændingen ved Hesselø på selvsamme tidspunkt, hvor vi egentlig skulle have været til sidste vejledning hos Niels Fock på baggrund af sammenskrivningen af vores kapitler om kunaindianerne.

Æret være hans minde.

Mindeordet er skrevet af Katja Kvaale, antropolog, mag.scient. (1997) 